\title{
Miranda
}

Revue pluridisciplinaire du monde anglophone /

Multidisciplinary peer-reviewed journal on the English-

speaking world

$21 \mid 2020$

Modernism and the Obscene

\section{Times of Contagion: The Social(ist) Politics of Plague in Naomi Wallace's One Flea Spare}

Essay

Laura Michiels

(2) OpenEdition

Journals

Electronic version

URL: http://journals.openedition.org/miranda/28377

DOI: 10.4000/miranda.28377

ISSN: 2108-6559

Publisher

Université Toulouse - Jean Jaurès

Electronic reference

Laura Michiels, "Times of Contagion: The Social(ist) Politics of Plague in Naomi Wallace's One Flea Spare", Miranda [Online], 21 | 2020, Online since 13 October 2020, connection on 16 February 2021. URL: http://journals.openedition.org/miranda/28377 ; DOI: https://doi.org/10.4000/miranda.28377

This text was automatically generated on 16 February 2021

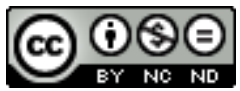

Miranda is licensed under a Creative Commons Attribution-NonCommercial-NoDerivatives 4.0 International License. 


\title{
Times of Contagion: The Social(ist) Politics of Plague in Naomi Wallace's One Flea Spare
}

Essay

\author{
Laura Michiels
}

We thought we were remaking ourselves. Perhaps we were. For each morning we were someone new and the world was almost a surprise, like biting into a piece of fruit with your eyes closed. (Wallace 70)

1 Sheerly by coincidence I started reading James Meek's To Calais, In Ordinary Time (2019) last March, when lockdown measures were first taken in Belgium, the country where I live. As far as I was aware, Meek's was a historical novel set during the Middle Ages, detailing the journey from Britain to France of a company of archers and several people who-unwittingly or not-become associated with them. What I did not realise is that the events unfold in 1348, when a significant segment of Europe's population succumbed to the Black Death, and that most of the characters would consequently never see their journey through. Of course, our current pandemic is nothing like the medieval plague in many ways: our odds of survival are better, due to improved health care and the nature of the disease, plus most of us do not tend to look to religion to cure us. And yet some similarities were striking. Take a look at the following passage from the novel:

The death, as they called it, had come to Heytesbury five days before, and already

slain

forty folk, men, women and children, a third of the town. None would go to their

neighbours' houses no more for fear they'd sick. Folk would hang cloths of their windows,

one to send for the priest, two to ask for food and drink to be left for them, three to have a

body borne away. The priest and the bell-ringer had gone to and from the homes of the sick

so often none paid them heed no more. The inn was shut, none came to town to buy the

cloth they made, the crops were ripe but none would harvest them, and half the 
cattle

lacked a master. (Meek 275- 276)

2 A fast-rising death toll, a sort of lockdown (self-imposed here), struggling businesses and wasted crops... Even though most aspects of Meek's novel felt very alien to me, these elements now were somehow familiar, which would not have been the case last year.

3 Since I am a theatre scholar, closed theatres were an important part of my lockdown experience. Theatre would have provided the perfect means to make sense of the present conditions, in that its association with contagion and plagues has been a long one. The Elizabethan Age is known as a golden era for theatre. Moralistic London authorities drove theatre companies to the suburbs where they built playhouses like the Theatre, which became highly successful. This idea about the development of $16^{\text {th }}$ century theatre in England is quite common. But according to David Kathman, several things are wrong with this picture. Most importantly for my purposes, Kathman asserts that the history of commercial theatre during the period was not one of unmitigated success but can be better understood in terms of economic booms and busts (42). The plague had more than a little to do with this because whenever the disease reared its head again, large gatherings were forbidden and theatres were forced to stay closed, sometimes for months on end. To someone like Shakespeare, who was a shareholder of the theatre where his plays were also performed, these occasions came at great financial cost (Greenblatt). And yet as Stephen Greenblatt points out, Shakespeare rarely portrays the plague. He uses it as a metaphor but hardly ever refers to the actual disease and the circumstances it brought about.

While the plague posed an economic threat to the theatre in Elizabethan times and served as a metaphor for things unhinged or malevolent in the work of its most famous representative, French director and actor Antonin Artaud posited several likenesses between theatre and the plague in his famous collection Le Théatre et son double (1938). These were not to be feared but welcomed. In Artaud's words:

If the essential theater is like the plague, it is not because it is contagious, but because like

the plague it is the revelation, the bringing forth, the exteriorization of a depth of latent

cruelty by means of which all the perverse possibilities of the mind, whether of an individual or a people, are localized.

Like the plague the theater is the time of evil, the triumph of dark powers that are nourished

by a power even more profound until extinction. (Artaud 30)

5 "Latent cruelty", "perverse possibilities", "time of evil" and "triumph of dark powers" may not sound very appealing to most people but were deemed necessary by Artaud. Only these would allow for the kind of thoroughgoing purification he envisioned. Only these would force us to confront the hypocrisy governing our society. No lockdowns required therefore.

6 Artaud has become known as a visionary, associated by most with freedom and experimentation. But this idea is, in Kimberly Jannarone's opinion, based on metaphorical readings of his work which do not take into account the specific historical context. She points out that the essays included in Le Théâtre et son double were written between 1931 and 1935, slightly more than a decade after the First World 
War and at the moment when a Second World War already was a distinct possibility. The images of carnage, disorder and stacks of dead bodies that can be found in "Le théâtre et la peste" were therefore hardly metaphorical to Artaud's contemporaries. They did not bring to mind the Middle Ages but the much more recent history made in the trenches (40). In light of this, it is perhaps even more problematic that such carnage is presented as desirable and necessary. Artaud envisioned "a nucleus of men capable of imposing this superior notion of the theater, men who will restore to all of us the natural and magic equivalent of the dogmas in which we no longer believe" (Artaud 32). The phrasing is patriarchal ("a nucleus of men"), implies force ("imposing") and hierarchy ("superior notion"). According to Jannarone, the essay resonates with the language not of freedom but of fascism (48).

7 In 1995, American playwright Naomi Wallace wrote One Flea Spare. She was equally inspired by violence and the plague yet the political slant of her text is very different. A native from Kentucky now living in North Yorkshire, UK, Wallace has become known for writing plays that are radical in terms of contents as well as form. She is a political playwright with a distinct interest in history and likes to investigate how different types of oppression (racial, gender, sexual, class etc.) intersect. Boundaries do not hold in her texts as the dead refuse to stay in their graves, picket lines and border fences are crossed, bodies are sliced open, past blends with present and houses are broken into. Wallace's socialist politics find expression in plays condemning the excesses of capitalism and imperialism.

One Flea Spare takes place in 1665 and is, for the most part, set at the London home of William and Darcy Snelgrave. The city is gripped by the plague and while many aristocrats have left for the safer countryside, the Snelgraves were "unlucky": their servants became ill, as a result of which they, too, were quarantined. At the beginning of the play, they have almost completed their 28 days of mandatory lockdown when a new accident befalls them. A sailor named Bunce and Morse, the supposed daughter of one of their aristocratic neighbours, break into the Snelgraves' home. Because these newcomers may have brought disease into the house, the guard Kabe decides that a new period of lockdown is necessary. The Snelgraves find themselves obliged to live in cramped quarters with a lower-class man and a child whom they have never met before and do not trust. Boredom leads to the disclosure of secrets, while class boundaries are slowly eroded. By the time the lockdown ends, both Snelgraves are dead, Bunce has escaped and Morse goes to jail, where she might also die.

9 The play was commissioned by London's Bush Theatre, where it was first performed in October 1995. One Flea Spare's American premiere occurred in February 1996 at the Actors Theatre during the Humana Festival of New American Plays in Louisville, Kentucky. In 1997, the play's first New York production took place at the Joseph Papp Public Theater/New York Shakespeare Festival. As often happens with Wallace's work, British critics were enthusiastic, while their colleagues across the Atlantic responded with lukewarm or even outright hostile reviews (Gornick). Ben Brantley in The New York Times called the 1997 production "stiff, schematic and surprisingly unaffecting" (Brantley) while the plot reminded him of Jean Genet's Les Bonnes (1947) without the older play's force or impact. Spectacularly negative, John Simon in New York Magazine wrote that the play is "not only pretentious and boring but also empty, pointless, and totally preposterous" (Simon 92). 

French by Dominique Hollier as Une puce, épargnez-la and performed at the Comédie Française's Théâtre Ephémère in 2012. Wallace became, after Tennessee Williams, the only other American playwright included in the company's permanent repertoire (Stevens Abbitt 276). The French production was highly stylised, a "postmodern version [...] [paying] clever homage to the paintings of old Masters and the masterpieces of French neoclassical theatre" (277). In the French magazine L'Express, Laurence Liban called the play "a sorrowful and agonizing meeting behind closed doors, against the backdrop of the plague and of puritanism" (Liban, translation mine). She praised AnneLaure Liégois's forceful direction as well as the performances of all five actors.

11 the play grew while riots were spreading like wildfire in Los Angeles after four police officers were not convicted of assault in the beating of Rodney King. Wallace herself says:

I'd been reading Daniel Defoe's Journal of the Plague Year when the riots broke out and I

began to see them both-L.A. and the London plague-as the same event. A time of crisis.

A time when rich and poor get thrown together-and, suddenly, one sees alternatives. I

began to think about what happens when the containment of a presumed danger through the

regimentation of space breaks down, such as when South-Central L.A. began to "invade" Beverly Hills. I wanted to foreground a society in crisis. By writing about a time other than

our own, it's possible for issues that have become locked in rhetoric, or dismissed as too

overdetermined for the stage, to become visible anew. (qtd. in Gornick)

While Rodney King was neither the first nor, unfortunately, the last African American to suffer abuse at the hands of the police, his violent encounter with LAPD was one of the first to be videotaped, which allowed it to go viral and outrage to spread widely (Arango). Today, racial inequality and excessive force have once again become the subject of nationwide debate and protest after white police officer Derek Chauvin kneeled on African American George Floyd's neck for almost nine full minutes, ignoring his cries of distress and killing him in the process. Whereas these gruesome events took place in Minneapolis, protest has arisen in most major cities across the country and in other parts of the world. In Los Angeles, it has become very difficult not to think back to the 1992 riots. But, following Tim Arango's assessment, we should be aware of some significant differences between the riots back then and now. The protesters during the nineties were mostly African Americans who stayed in the then black neighbourhood of South Central. The current protesters are, conversely, of different racial backgrounds and are taking their discontent to the wealthy white neighbourhood of Beverly Hills. This because "rage and anger over racism and police abuses have been compounded by outrage at another of America's most profound issues-growing income inequality" (Arango).

Even though race riots were on Wallace's mind when she started writing One Flea Spare, race does not seem to play a major part in the text. No reference is made to the characters' racial background and since the Snelgraves are aristocrats in $17^{\text {th }}$-century London and Morse can pass for one, they are almost certainly white. The only character 
who might be of colour is mentioned in one of Bunce's stories about life at sea. Bunce talks about a fellow-sailor named Killigrew, whom he loved. At Mrs Snelgrave's request, he describes Killigrew's breast which was "Darker. Like the skin of an apple it smelled, and as smooth" (Wallace 31). Given the play's association between fruit and eroticism, Bunce here appears to hint at his strong desire for this darker sailor. Killigrew and Bunce fought side by side against the Dutch yet the former was "luckier": he died, allowing him to escape further impressment.

Bunce's life so far has, to a large extent, been a product of his class background. Unlike race, class is very important in Wallace's text, which explains Brantley's complaint that the plot feels like "a Marxist economics class" (Brantley). According to Brantley, the plague creates "a climate in which illness and death are, if nothing else, democratic" (Brantley). But this claim glosses over some of the finer details of the plot. Wallace herself recently explained that she sees the plague and economic injustice as catastrophes that are equally destructive:

It's also about pestilence on top of pestilence, as we have today: a dangerous virus on top of

a destructive economic system. That's twice the blow. For me, it's about imagining a

radically different world, reenvisioning the way we relate to one another. (Wallace, qtd. in

Rodriguez)

Although the plague is not democratic in that it hits the poor harder, it does allow class boundaries to erode over time.

One Flea Spare includes five characters: the Snelgraves are aristocrats, Bunce and Kabe are lower-class and Morse hovers somewhere in between because she is a class pretender. As mentioned, the Snelgraves are still in London by accident rather than choice. Everyone else of their class has left the city, including the king and his courtiers. Vividly describing one of the pits where the plague's many victims are buried, Kabe explains that

The hungry. The dirty. The abandoned. That's who dies. Not the fancy and wealthy, there's

hardly a one, for they have fled, turned their back on the city. Clergymen, physicians and surgeons, all fled. (Wallace 39)

17 However, the Snelgraves find themselves locked up by a lower-class man, forced to share their house with two lower-class characters. Theirs will be a different fate altogether.

The plague that spread across the world during the $14^{\text {th }}$ century was a catastrophe by any standard. But not all of its side effects were negative. The disease "almost instantly reordered long-standing social relations between rich and poor, lord and serf, turning the tables on Europe's ruling elite in previously unimaginable ways" (Roos 27). Because labour was scarce, workers were able to demand higher wages. The ruling classes were scared by what felt like a topsy-turvy world to them and tried to limit wages and forbid workers from dressing like them.

One Flea Spare is set during the $17^{\text {th }}$ century but the plague equally seems to loosen class restraints within the specific context of the Snelgrave household, at least temporarily. This is the result of the 28-day lockdown: sharing the same two rooms with virtually nothing to do obliges the characters to look for entertainment in unexpected corners. 
Initially, Bunce is not allowed to be around the other three characters at all times. He is engaged as a servant, continuously expected to clean the house with vinegar, and locked up, leading to a sort of lockdown within the lockdown. Yet from the very beginning this arrangement is destined to fail. The Snelgraves, firstly, do not realise that while they lock away one lower-class character, they are sharing a room with another. Morse is, after all, not whom she claims to be. The Snelgraves unquestioningly accept her as "one of us" (Wallace 13) without a shred of evidence. Meanwhile Mr Snelgrave tells his new servant

I'm not a cruel man, Bunce. But even under these conditions I can't just let you walk

about.

This is my home. Under my protection. The problem is that you have the only suitable

room in the house because it has a door that I can lock and we must sleep on the

kitchen

floor. (Wallace 13)

Bunce inadvertently benefits from the Snelgraves' fastidiousness about class separation, in that he sleeps in a nice room and they have to make do with the kitchen floor.

Clothing plays an important role in breaking down class barriers. Dressing up and crossdressing are common occurrences in Wallace's plays yet in this case a historical precedent can be found. As mentioned, the upper classes in medieval Europe were angered by lower-class women and children wearing clothes previously owned by wealthy plague victims and tried to prevent them from doing so (Roos 27). Morse manages to pull off her upper-class charade thanks to her dead mistress's dress. She enters the Snelgrave household claiming that she is Sir Nevill Braithwaite's daughter. While Mr Snelgrave is somewhat suspicious of her behaviour because "Sir Braithwaite's daughter doesn't climb over roofs. Sir Braithwaite's daughter doesn't enter uninvited" (Wallace 13), he quickly accepts her based mainly on appearances. Even after Kabe tells him that all three members of the Braithwaite family, including the daughter, were found dead, Snelgrave is not inclined to believe him: "She can't be dead! She's alive and well and a pest in my house" (Wallace 40).

How does Morse end up dressed up like an upper-class young woman? After $\mathrm{Mr}$ Snelgrave has died, Morse tells him about her own mistress's death. She used to serve a girl named Lissa, who was in severe pain during her final moments and asked Morse to hold her. Morse seized the opportunity to bargain and would only hold her employer if she gave up her shoes and dress. By the time this transaction was completed, Lissa had already gone. While it may seem cruel to barter with a dying, by now blind girl, Morse repeatedly describes the cruelty she herself suffered at the family's hands. Lissa routinely beat her with a stick while she was going about her duties and Sir Braithwaite locked up Morse's mother as soon as she presented with symptoms of plague. He neither allowed his servant to see her daughter nor did he give her any food. Snelgrave even suggests that Sir Braithwaite might have been Morse's father, since "[m]asters make free with their maids" (Wallace 59). Little surprise then that she has few scruples about stealing from Sir Braithwaite and his ilk.

Bunce's journey across class borders develops differently but also involves clothing. As mentioned, Bunce at first spends his time sequestered from the other characters to maintain the semblance of social hierarchy. However, a combination of boredom and desire leads both Snelgraves to spend protracted periods of time with him. $\mathrm{Mr}$ 
Snelgrave lets Bunce wear his shoes, mainly to see what will happen, because "[h]istorically speaking, the poor do not take to fine shoes. They never have and they never will" (Wallace 26). To Bunce, this statement does not ring true and he wonders why he cannot just keep the shoes, since Snelgrave owns other pairs. Darcy and William Snelgrave both want to find out about Bunce's life at sea, with a special interest in his sexual history. By entertaining his hosts with stories of mutiny and licentious behaviour, Bunce secures his freedom. Yet these stories which the Snelgraves so avidly want to hear and order Bunce to tell, ultimately also contribute to undermining the household's hierarchy. Mr Snelgrave wants to find out every detail about the things desire led Bunce to do on board a ship with only men, but is less than pleased when the sailor volunteers information about his desire for Mrs Snelgrave. The violence ensuing from this particular conversation leaves Mr Snelgrave restrained in a chair, giving Bunce the opportunity to take his clothes, including the shoes he had previously tried on.

Whereas the power dynamics inside the newly minted Snelgrave household are prone to change, all four characters are temporarily at the mercy of a lower-class force, namely the watchman Kabe. It is Kabe who decides that the Snelgraves will spend an additional 28 days locked down together with their new house guests. Three of the people inside the house try to bargain with him yet only one appears to be successful. Morse wants a certificate which will allow her to leave the city but Kabe claims that these are impossible to come by. Instead they end up making a deal involving delicacies and sexual favours. Mr Snelgrave wants to buy items to keep the plague at bay and has no choice but to overpay. Kabe rejects his other offer of riches in exchange for freedom. When Bunce attempts to make the same deal, using Snelgrave's money, the guard is more willing to comply because he does not "care enough about you to hate you. Rabble" (Wallace 66). Even though these words seem hardly complimentary, Kabe himself had been identified as rabble in an earlier conversation with Morse. A shared class background combined with a radical family history may lead to his decision to help Bunce rather than Mr Snelgrave.

During one of his own conversations with the guard, Mr Snelgrave had correctly recognised a strain of radicalism in Kabe: "The dying is done in this house, I thank the Lord. And when the dying is done in this city, Kabe, you better run, because I smell a Leveller's blood in you, ringing loud and clear. I thought we buried the lot of you" (Wallace 41). Kabe claims to be innocent of the beliefs he is accused of but does admit that his father was a Leveller. These casual remarks are easily missed yet they hint at a buried layer of radicalism, at another catastrophe leading to ideas about societal renewal. The Levellers constituted a political movement active during the English Civil Wars of the 1640s, a series of armed conflicts between those loyal to the King (Royalists) and those who favoured the British Parliament (Parliamentarians). The Levellers were disappointed by the violence used by the government and wanted to rethink the role played by Parliament. They did not want to think of Parliament as a body representing the nation but as an employee of the nation (Appelbaum 131). Citizens are, according to the Levellers, defined by natural rights and can pass on their opinion through representatives. By means of their Agreement of the People, the Levellers advocated for a representative democracy (136).

Yet these ideas were not radical enough for the tastes of some. Mr Snelgrave is happy to hear that Kabe's father has choked: "A proper death for a man of his station. 
Levellers. Diggers. I say cut them to pieces or they will cut us to pieces" (Wallace 41). It seems safe to say that Mr Snelgrave is a fan of neither levellers nor diggers and tends, as opponents of these separate movements were wont to do, to conflate the two (Hughes 218). The Diggers had, in part, brought this upon themselves by using the label "True Levellers" in their first publication. This because the actual Levellers had just issued a statement to counteract the common perception that they posed a serious economic threat and were in favour of levelling estates (Gurney 123). The Diggers, by contrast, were a radical movement in England during the 1640s associated with Gerrard Winstanley. They believed that the earth belonged to everyone, that private property should be abolished, as should buying and selling (viii). The Diggers had turned this theory into practice by digging on St George's Hill in Surrey. While neither the Levellers nor the Diggers saw their ambitions realised, the 1640s wars did result in major change, at least temporarily: the execution of King Charles I and Britain's brief stint as a republic, "in a sense, the single most utopian thing ever attempted in British political history" (Appelbaum 102). The aristocracy lost some of its power and a remarkable freedom to publish and preach could be observed (J. Miller 3).

It is not entirely surprising that a movement like the Diggers should come into being in the wake of a civil war that led to regicide, at least if one is inclined to believe the ideas set forth by Walter Scheidel in his 2017 study The Great Leveler: Violence and the History of Inequality from the Stone Age to the Twenty-First Century. Scheidel discusses the "Four Horsemen of Leveling", namely mass warfare, violent revolution, state collapse and lethal pandemics (Scheidel 6). According to Scheidel

Violent shocks were of paramount importance in disrupting the established order, in

compressing the distribution of income and wealth, in narrowing the gap between rich and

poor. Throughout recorded history, the most powerful levelling invariably resulted

from the

most powerful shocks. (6)

Various critics and commentators have noted that the current moment feels like another turning point. Obviously, it is impossible to predict where the present crisis will leave us. But, as Jerome Roos points out, krisis was an important term in Hippocratic medicine: it indicated the in-between moment when a disease could either become worse and lead to death or when recovery was starting (24). The Black Death spelled the demise of the Middle Ages and its feudal system. Roos wonders whether the current pandemic could mean the end of late modernity (24). Clare Cain Miller, for her part, asserts that "[h]istorically major crises have tended to empower workers" (C. C. Miller). The examples she gives are, again, the Black Death and its connection to feudalism but also the New Deal, which came about as a result of the Great Depression. Miller acknowledges that the current pandemic is not as threatening as the plague but points out that it does come at a moment when discussions about income inequality were already raging in the US. The present situation may not lead to improved conditions for workers because many people have lost their jobs and the disease has worsened inequality in that it struck African Americans and Latinos disproportionately hard (C. C. Miller). Yet at the same time, expectations have been adjusted: many companies have, for instance, awarded benefits like paid sick leave. Even if these policy changes were supposed to be temporary, it could prove difficult to revert to the old situation. 

Snelgraves have died, which, in a way, could seem to indicate the end of the old order. But matters are far more complex than a simple "out with the old, in with the new". Mrs Snelgrave's life is ended by Morse. Of course, the story of an aristocrat put to death by a former servant smacks of revolution. However, in this particular case, it is actually an act of love. Mrs Snelgrave has contracted the plague and is in great pain. She initially asks Bunce to take her life yet he refuses because he "ha[sn't] the courage" (Wallace 71). Morse complies after another round of bartering, which leaves her with Darcy's gloves. Even though Bunce escapes as far as we are aware, he himself does not have high hopes about his chances of survival now that the Snelgraves are gone: "It is done. We are dead" (Wallace 72). After Mr Snelgrave's death, Bunce had already pointed out to Morse that he "might as well rope [him]self and walk to Tyburn. Save them and [him] the trouble" (Wallace 66). Morse actually ends up in prison where she is compelled, through violence, to discuss what happened during the lockdown. Bunce's prediction may have come true, in that the first question she is asked is "What are you doing out of your grave?" (Wallace 7). If four out of the five characters die, the picture we are left with appears rather bleak.

A final twist turns our attention to love and desire. Morse's last words to us are about love: "Because I loved them, and they have marked me" (Wallace 74). While Kabe is singing another one of his songs, she throws an orange in the air and "[j]ust as she catches it, the lights go black" (Wallace 74). The orange had earlier served as a prop in one of Bunce's stories about desire at sea. Throughout the play a connection between desire and fruit is developed: Morse lets Kabe touch her based on the promise of apples and tangerines, while the quote I used as an epigraph for this article is part of Darcy's description of her formerly passionate sexual history with Mr Snelgrave. As mentioned, it is desire combined with boredom which breaks down various barriers over the course of the play. To Wallace, rediscovering love and desire is another act of subversion, another hidden layer of radicalism because "[i]n our society, the body is a thing made instrumental use of, and then asked to be-meant to be, unable to be-a thing of love" (qtd. in Gornick). Desire, then, "serves the need to end one's singular state. It creates the space in which to reimagine oneself" (qtd. in Gornick). Morse's final disobedient gesture allows her to escape confinement and swings open the door to that space, which we are invited to enter with her.

\section{BIBLIOGRAPHY}

Appelbaum, Robert. Literature and Utopian Politics in Seventeenth-Century England. Cambridge: Cambridge UP, 2002.

Arango, Tim. "In Los Angeles, the Ghosts of Rodney King and Watts Rise Again.” The New York Times, 03 June 2020. Accessed 08 June 2020.

<https://www.nytimes.com/2020/06/03/us/rodney-king-george-floyd-los-angeles.html> 
Artaud, Antonin. The Theatre and Its Double. Translated by Mary Caroline Richards. New York: Grove Press, 1958.

Brantley, Ben. "Prisoners in Their Own Home, Facing the Twin Ravages of Plague and Power." The New York Times, 10 March 1997. Accessed 05 June 2020.

<https://www.nytimes.com/1997/03/10/theater/prisoners-in-their-home-facing-the-twinravages-of-plague-and-power.html>

Gornick, Vivian. “An American Exile in America.” New York Times Magazine, 2 March 1997. Accessed 16 Nov. 2017.

<https://www.nytimes.com/1997/03/02/magazine/an-american-exile-in-america.html> Greenblatt, Stephen. "What Shakespeare Actually Wrote About the Plague.” The New Yorker, 07 May 2020. Accessed 05 June 2020.

<https://www.newyorker.com/culture/cultural-comment/what-shakespeare-actually-wroteabout-the-plagues

Gurney, John. Brave Community: The Digger Movement in the English Revolution. Manchester: Manchester UP, 2007.

Hughes, Ann. "Diggers, True Levellers and the Crisis of the English Revolution." In The Agreements of the People, the Levellers, and the Constitutional Crisis of the English Revolution. Eds. Philip Baker and Elliot Vernon. Basingstoke: Palgrave Macmillan, 2012. 218-238.

Jannarone, Kimberly. Artaud and His Doubles. Ann Arbor: U of Michigan P, 2010.

Kathman, David. "The London Playing Bust of the Early 1580s and the Economics of Elizabethan Theater." Shakespeare Studies 45 (2017): 41-50.

Liban, Laurence. “Une puce, épargnez-la à la Comédie Française.” L’Express, 19 May 2012.

Accessed 09 June 2020.

<https://www.lexpress.fr/culture/scene/naomi-wallace_1114910.html>

Meek, James. To Calais, in Ordinary Time. Edinburgh: Canongate, 2019.

Miller, Claire Cain. "Could the Pandemic Wind Up Fixing What's Broken About Work in America?" The New York Times, 10 Apr. 2020. Accessed 05 June 2020.

<https://www.nytimes.com/2020/04/10/upshot/coronavirus-future-work-america.html>

Miller, John. A Brief History of the English Civil Wars: Roundheads, Cavaliers and the Execution of the King. London: Constable \& Robinson, 2009.

Rodriguez, Giovanni. "Naomi Wallace's Theatre of the Plague: More Riveting and Relevant Than Ever." Forbes, 10 May 2020. Accessed 05 June 2020.

$<$ https://www.forbes.com/sites/giovannirodriguez/2020/05/10/naomi-wallaces-theatre-of-theplague-more-riveting-and-relevant-than-ever/\#6c2f36375602>

Roos, Jerome. "How Plagues Change the World.” New Statesman 149:5520 (2020): 24-28.

Scheidel, Walter. The Great Leveler: Violence and the History of Inequality from the Stone Age to the Twenty-First Century. Princeton: Princeton UP, 2017.

Simon, John. “Flea-Bitten.” New York Magazine, 24 March 1997, pp. 92-93.

Stevens Abbitt, Erica. "Une puce épargnez-la (One Flea Spare)." Theatre Journal 65:2 (2013): 275-277.

Wallace, Naomi. In the Heart of America and Other Plays. New York: Theatre Communications Group, 2001. 


\section{ABSTRACTS}

Naomi Wallace's One Flea Spare (1995) was inspired by Daniel Defoe's Journal of the Plague Year and the LA riots that followed the acquittal of four policemen after they had beaten Rodney King. To her, these events became linked, because spatial barriers broke down, obliging the rich and poor to share a common space. The play is set in $17^{\text {th }}$-century London at a time when the city is ravaged by the plague. Four characters are quarantined together against their will, which leads to extraordinary situations. Several critics have noted that the plague can be seen as a leveller but I would actually like to qualify this idea, in that the disease mainly kills the poor in the play and the power shift it portrays seems to be temporary at best. At the same time, I want to explore the text's hidden layers of radicalism, which it could be argued are a by-product of catastrophe.

«Une puce, épargnez-la» (1995) de Naomi Wallace a été inspiré par «Le journal de l'Année de la peste» de Daniel Defoe et les émeutes à Los Angeles qui ont suivi l'acquittement de quatre policiers après avoir battu Rodney King. Selon elle, ces événements sont liés parce que pendant ces faits, les barrières sont tombées, obligeant les riches et les pauvres à partager un espace commun. La pièce se déroule dans le Londres $d u 17^{\text {ème }}$ siècle, à une époque où la ville est ravagée par la Grande Peste. Quatre personnages sont mis en quarantaine contre leur gré, ce qui conduit à des situations extraordinaires. Plusieurs critiques ont noté que la peste peut être considérée comme un élément niveleur, mais je voudrais en fait nuancer cette idée, dans la mesure où la maladie tue principalement les pauvres dans la pièce et le changement de pouvoir qu'elle représente semble être, au mieux, temporaire. En même temps, je voudrais explorer le radicalisme du sous-texte, qui pourrait être considérées comme un sous-produit de la catastrophe.

\section{INDEX}

Keywords: Naomi Wallace, One Flea Spare, political theatre, plague, radical politics, class differences

Subjects: Theater

Mots-clés: Naomi Wallace, Une puce, épargnez-la, théâtre politique, peste, radicalisme, inégalités sociales

\section{AUTHORS}

\section{LAURA MICHIELS}

English lecturer

Erasmus Brussels University of Applied Sciences and Arts

lauramichiels2@gmail.com 